\title{
Development of Interactive Teaching Materials for the Freier Vortrag Course to Improve the Speaking Competence of Students of the German Education Study Program
}

\author{
Tri E. Lestari ${ }^{1, *}$ Dwi I. Julaikah ${ }^{1}$ Agus Ridwan ${ }^{2}$ Novia R. L. Ramadhani ${ }^{3}$ \\ 1,2,3 Faculty of Languages and Arts, Universitas Negeri Surabaya 60213, Indonesia \\ "Corresponding author. Email: triedlianilestari@unesa.ac.id
}

\begin{abstract}
The general objective of this research is to develop interactive teaching materials for the Freier Vortrag course to improve speaking competence of students of the German Language and Literature Department. The specific objectives of this study are (1) to describe the process of developing Freier Vortrag introductory teaching materials to improve the students' speaking competence (2) to describe the product quality of developing Freier Vortrag teaching materials to improve students' speaking competence. This development research uses the concept of Borg and Gall. The existence of textbooks whose content is adjusted to the RPS (Semester Learning Plan) can be a study guide for students and make it easier for students to understand the Freier Vortrag lecture material. The material presented in the textbook consists of five chapters, namely Basic Concepts of Speeches, Speeches in the World of Education, Speeches in the World of Politics, Speeches in the World of Business, and Speeches in the World of Work. The analysis results of the textbook can be declared suitable to be used as a learning instrument at the Department of German Language and Literature, Universitas Negeri Surabaya, because it helps students in achieving learning objectives.
\end{abstract}

Keywords: Freier Vortrag, Techniques and basics of speech, Redemittels in speech.

\section{INTRODUCTION}

Speaking competence, especially in making speeches, is one of the competencies that supports the profile of graduates from majors. While speaking German, a speaker uses various methods and techniques and various media. The results of the speech produced also vary from one individual to another depending on the language skills and knowledge possessed and the techniques and media chosen. Speech is not just an activity of "talking" or reading a speech in German, but in making a speech, the main goal must be achieved, namely to make listeners understand the meaning of the speaker or even lead their opinion. Speech is therefore also called the mediation process between the speaker and the listener. This mediation process itself requires a technique so that it can achieve the expected goals. It cannot be separated between making or preparing a script with one's technique in giving a speech, if a speaker wants to achieve a specific goal to make a speech well and easily understood. It is in line with the opinion of
Nunan [1], who concluded that speaking as a communicative competence includes (1) knowledge of the grammar and vocabulary of that language; (2) knowledge of the rules of speech (for example, knowing how to start and end a conversation, knowing what topics can be discussed in different types of speech events, knowing which forms of greeting to use with other people) different people to talk to and in different situations (3) knowing how to use and respond to various speech acts such as requests, apologies, thanks, and invitations; and (4) knowing how to use language appropriately.

The German Language Education Study Program to produce graduates with competent speaking competence presents the Freier Vortrag course as a scientific course that students must take. The Freier Vortrag Lecture applies Project Based Learning by focusing on project tasks of making speeches, media, and speeches to realize learning outcomes in accordance with those stipulated in the Merdeka Learning curriculum. In implementing 
theory to the practice, it is needed and provided teaching materials in real examples and in accordance with the latest developments. Therefore, the development of teaching materials for Freier Vortrag courses needs to be carried out to support the realization of course learning outcomes and produce graduates who are more competent in speaking German in various themes.

\subsection{Theory of Development of Teaching Materials}

Teaching materials are all materials (both information, tools, and texts) that are systematically arranged, which displays a complete figure of competencies that will be mastered by students and used in the learning process to plan and study the implementation of learning [2]. Learning are materials or subject matter arranged thoroughly and systematically based on the learning principles used by teachers (lecturers) and (students) in the learning process. Teaching materials are systematic, meaning they are arranged in order, following the system development process, making it easier for students to learn. In addition, teaching materials are also unique and specific. Unique means that teaching materials are only used for certain goals and in certain learning processes. While specific means that the contents of teaching materials are designed in such a way only to achieve certain competencies from certain targets [3]. The function of teaching materials, among others, is the main source of main learning, as a compliment, and as enrichment material. The development principles include correctness of content/concepts, completeness/wholeness in learning, simplicity in presentation, balance in pages, firmness in message presentation, beauty in appearance, forthcoming in message delivery, and edutainment for delivery readers.

The objectives of the learning materials developed include: achieving learning objectives, demands for independent learning, needs for learning types, spread knowledge, continuity of knowledge, as well as for commercial purposes. The types of learning materials can be categorized as follows: a) printed learning materials, for example, hand-outs, books, modules, student worksheets, brochures, leaflets; b) Non-printed learning materials, for example, audio, radio, video learning, interactive multimedia learning, and the internet. The Ministry of National Education [4] reveals "the development of teaching materials should pay attention to the following learning principles: (1) starting from the easy to understand the difficult, from the concrete to understanding the abstract; (2) repetition strengthens understanding; (3) positive feedback reinforces students' understanding; (4) high motivation is one of the determinants of learning success; (5) achieve the goal; and (6) knowing the results achieved".
According to Prastowo [5] in terms of shape, teaching materials can be divided into four types, namely:

(1) Printed teaching materials (printed), namely several materials prepared on paper, can function for learning purposes or information delivery. For examples: hand-outs, books, modules, student worksheets, brochures, leaflets, wall charts, photos/pictures, models, or mock-ups.

(2) Hearing teaching materials (audio) or audio programs: all systems that use radio signals directly, which can be played or heard by a person or group of people. Examples: cassettes, radios, LPs, and compact disc audio.

(3) Hearing teaching materials (audiovisual): everything that allows audio signals to be combined with moving images sequentially. Examples: video, compact disk, and film.

(4) Interactive teaching materials (interactive teaching materials): a combination of two or more media (audio, text, graphics, images, animation, and video) which users manipulate or treat to control order and or natural behavior of the presentation. Example: interactive compact disk.

The significance of developing teaching materials is to realize the availability of teaching materials according to student needs, curriculum demands, target characteristics, and learning problem-solving demands. The development of teaching materials must be in accordance with the demands of the curriculum, meaning that the teaching materials developed must refer to content standards and graduate competency standards.

\subsection{Vortrag (Speech)}

Vortrag in Duden Online is "Rede über ein bestimmtes [wissenschaftliches] Thema" or talking about a certain scientific topic. Before we can give a speech, we must plan and prepare it. Things that must be prepared and discussed in the first, second and third sections according to Westhoff [6]:

(1) Planning and preparation of speeches. We can give lessons after careful planning and preparation and without text.

(2) During Speech

(3) Illustration of good feedback to respond to speeches, regarding the number of listeners who have problems giving feedback.

Westhoff [6] also states every speech design process should begin by clarifying what goals you want to achieve. We can ask ourselves: what do I want? Or what I don't want? In describing the goals themselves, it can help to help achieve our goals in doing speeches, and this can be clarified by making brief notes. 
To make it easier, we can also record it with keywords. Possible goals and desires could be to inform listeners about the topic in such a way that they can:

(1) find topics of interest;

(2) understand and remember important things;

(3) find a real approach;

(4) able to understand and evaluate methodological approaches;

(5) can report the results to others;

(6) experience expertly discussed findings.

Feedback on speech is an activity of speaking in front of a crowd to convey a goal or idea, thought, or information from the speaker to others verbally [7]. Making a speech is related to rhetoric, which is the art of using language effectively, which is also interpreted as the art of persuasion. The art of persuasion itself is the art of persuading or influencing the audience. According to Badudu and Zain [8], speech is the delivery of ideas, thoughts, or information and the goals of the speaker to others (audience) verbally. Speech can also be interpreted as the art of persuasion, namely, persuading or influencing. A good speech can make a positive impression on those who hear it. The ability to give a good speech or public speaking can help to achieve a good career path.

\section{METHODS}

The method used in this research is the Research and Development method or development method. According to Borg and Gall [9], development methods are applied to produce specific products and test the effectiveness of these products. The product being developed is the Freier Vortrag textbook. This textbook is an interactive textbook that presents or inserts examples in the form of audio-visual to make the reader more interested and get a clear picture of how to speak in German. The product specification of this textbook is that the material presented in the textbook consists of five chapters, namely Basic Concepts of Speech; Speeches in the World of Education; Speeches in the World of Politics; Speech in the Business World; and Speech in the World of Work; and all the themes presented will also provide examples of YouTube video links according to the theme. In addition to video sample speeches, this book will also offer preparatory stages, starting from writing the script, media to Redemittel, which is commonly used in a speech, and do not forget to give feedback. Overall this research involves three stages, namely 1) the preliminary study stage (field observation and literature study), 2) the development study stage (teaching material analysis, prototype design, development of teaching materials), and the evaluation stage (testing the effectiveness of teaching materials.
The subjects in the study were students of the 2019 class of education study program majoring in German Language and Literature, Faculty of Language and Arts, Universitas Negeri Surabaya, amounting to 14 people. The research was conducted in the odd semester of 2021 in the German language and literature department, Faculty of Language and Arts, State University of Surabaya. The data analysis used in this research is an interactive qualitative analysis model technique, which consists of three components, namely; (1) data reduction, (2) data display, and (3) conclusion or verification [10].

The procedure of this research, according to Borg and Gall [9] includes 1) the preliminary study stage through FGD to obtain responses from students as potential users of teaching materials, 2) the stage of developing teaching materials into prototypes and developing prototypes into teaching materials, and 3) evaluation stages to test the effectiveness and feasibility of teaching materials. The three procedures are described in more detail in Figure 1 as follows.

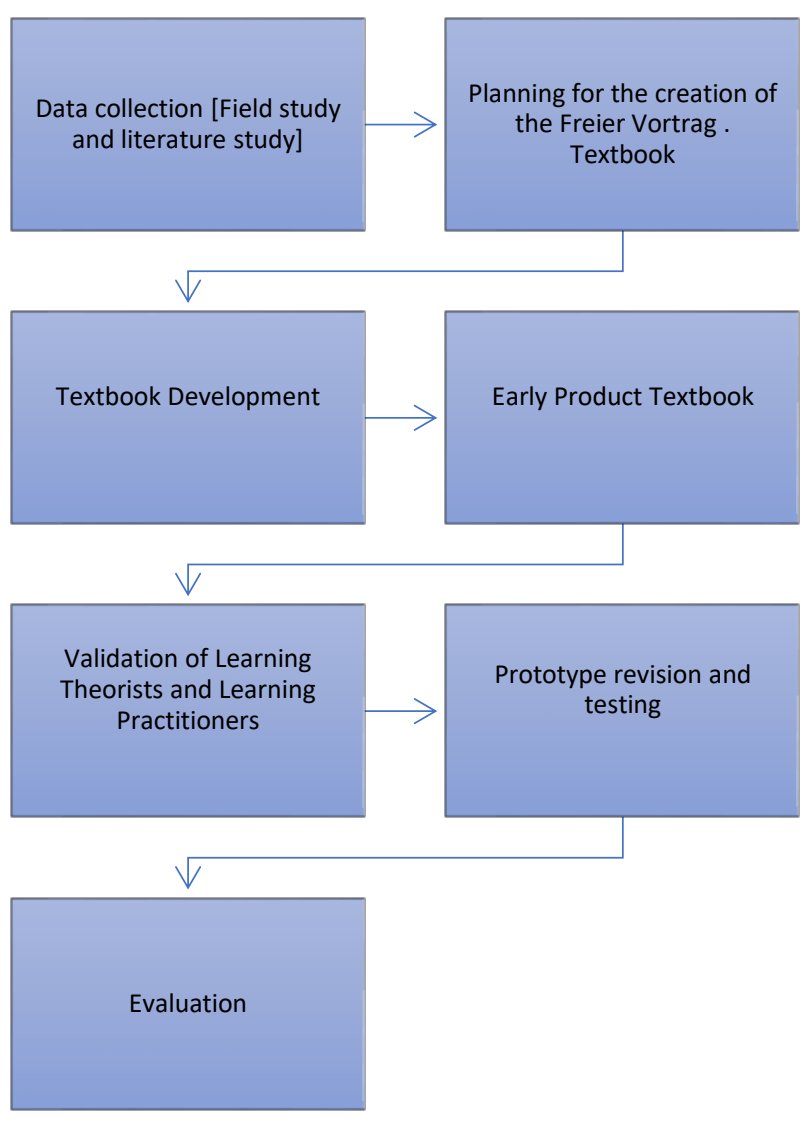

Figure 1 Chart of Textbook Research Procedures.

\section{RESULTS AND DISCUSSION}

This research is a design/development research to produce teaching media in teaching materials to assist student learning activities in the Freier Vortrag course. The difference between this study and existing research 
is that other research aims to increase student participation in the Freier Vortrag course. For this purpose, a research process scenario is prepared, divided into two: preparing a Semester Learning Plan (red: Rencana Pembelajaran, RPS) and conducting a final analysis to determine the type or form of teaching materials.

The Department of German Language and Literature has not had a textbook on Freier Vortrag, even though it has been included in the curriculum for years. Based on the results of interviews with several lecturers who teach Freier Vortrag courses, they stated that they had taken references from several universities in Germany so far. Based on the analysis of the curriculum of the German Language and Literature Department, before compiling the Freier Vortrag textbook, an RPS was prepared in accordance with the course description and several related references. Based on the RPS that has been collected, developed into a textbook according to the needs of students.

\subsection{Learning Instrument Validation Results}

The preparation of Freier Vortrag's textbook consulted with several materials, language, and graphic experts. The textbook was further validated by four Faculty of Language and Arts, State University of Surabaya. The validator assesses by checking $(\sqrt{ })$ the list of indicators listed, and the researcher processes the rating. The criteria for instrument validation include (a) Textbook Structure, (b) Material Writing Organization, and (c) Language.

Based on the results of the average assessment of the four validators, the structural aspect of the textbook obtained a percentage of $80 \%$. Meanwhile, in the organizational aspect of writing material, the textbook received an assessment of $84.75 \%$. On the third aspect, namely, language received an $82 \%$ rating.

The results of the validation of the textbooks from the three assessment aspects are displayed in Figure 2.

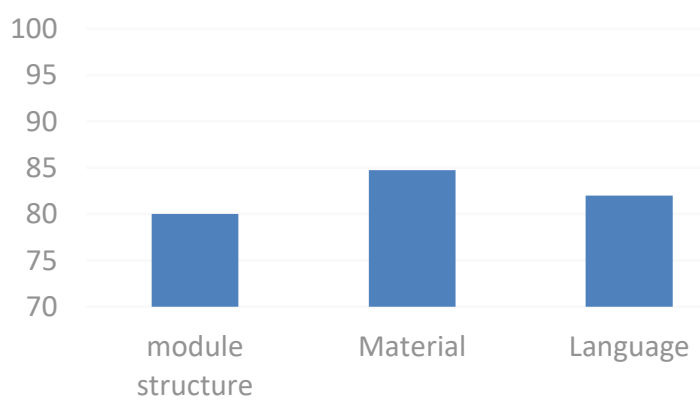

Figure 2 The results of the validation of the textbooks from the three assessment aspects.

Based on the assessment results of the three aspects, the average value of the three reached $82.25 \%$. Thus, the
Freier Vortrag textbook can be categorized as valid with a final rating of $82.25 \%$. It is suitable for use as a learning instrument in the Department of German Language and Literature, State University of Surabaya.

\subsection{Student Response Questionnaire Results}

After the student response questionnaire was validated, this questionnaire was given to 20 Indonesian Language Education students batch 2019. The questionnaire results were used to determine student responses regarding the content of the Freier Vortrag textbook. Figure 3 is the result of the student response questionnaire in graphic form.

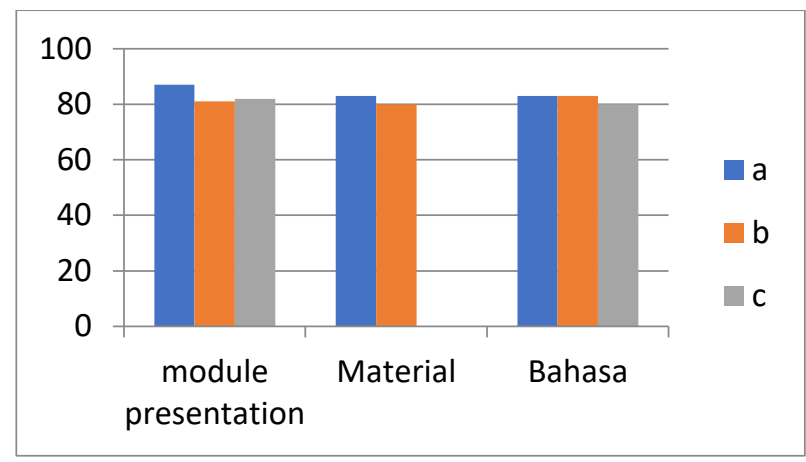

Figure 3 The result of the student response questionnaire.

Based on the student response questionnaire results, it was found that the total student response score using the formula was $82.37 \%$. With the acquisition of these scores, it can be concluded that the use of this Freier Vortrag module in Freier Vortrag learning gives excellent results.

\section{CONCLUSION}

Based on the formulation of the problem and the results of the data obtained in the study, it can be concluded that based on the results of the validation of the textbooks carried out by fellow lecturers of German Language and Literature at Unesa, the Freier Vortrag textbook obtained a score of $80 \%$ on the criteria for Textbook Structure. It is $84.75 \%$ on Material Writing Organization criteria and $82 \%$ on Language criteria. Thus, the overall score is $82.25 \%$. The textbook can be declared suitable for use as a learning instrument at the Department of German Language and Literature, State University of Surabaya.

\section{AUTHORS' CONTRIBUTIONS}

The authors contributed to the design and implementation of the research, the analysis of the results, and the manuscript's writing. 


\section{ACKNOWLEDGMENTS}

The research entitled "Development of Interactive Teaching Materials for the Freier Vortrag Course to Improve the Speaking Competence of Students of the German Education Study Program" is one of the outputs of research activities carried out by the author at the Universitas Negeri Surabaya. The authors would like to express the deepest gratitude to all parties who have helped this research and all students who have participated. The author hopes that this research will broaden the horizons of the readers.

\section{REFERENCES}

[1] D. Nunan, Second language teaching \& learning, Boston, MA: Heinle \& Heinle, 1999.

[2] A. Prastowo, Panduan Kreatif Membuat Bahan Ajar Inovatif, Yogyakarta: Diva Press, 2012.

[3] Sungkono, Pengembangan dan Pemamfaatan Bahan Ajar Modul Dalam Proses Pembelejaran, Yogyakarta.FIP UNY, 2003.
[4] Depdiknas, Peraturan Pemerintah RI No.19 Tahun 2005 tentang Standar Nasional Pendidikan, Jakarta: Depdiknas, 2008.

[5] A. Prastowo, Panduan Kreatif Membuat Bahan Ajar Inovatif, Yogyakarta: Diva Press, 2013.

[6] K. Westhoff, Der freie wissenschaftliche Vortrag Eine Anleitung, Bonn: Deutscher Psychologen Verlag, 1999.

[7] F.A. Yanuarita, Memaksimalkan Otak Melalui Senam Otak (Brain Gym), Yogyakarta : Teranova Books, 2012.

[8] B. Badudu and Z. Zain, Kamus Umum Bahasa Indonesia, Jakarta : Pustaka Sinar Harapan, 2001.

[9] W.R. Borg and M.D. Gall, Educational Research: An Introduction, Fifth Edition, New York: Longman, 1983.

[10] M. Milles and H. Huberman, Analisis Data Kualitatif, Jakarta: Universitas Indonesia Press, 1992. 